\title{
TINGKAT KEPUASAN PASIEN PESERTA BPJS KESEHATAN TERHADAP MUTU PELAYANAN KESEHATAN DI UPTD PUSKESMAS RAWAT INAP CIRANJANG
}

\author{
Poni Sapitri ${ }^{1 *}$, Irda Sari ${ }^{2}$ \\ Politeknik Piksi Ganesha, Bandung ${ }^{1,2}$ \\ Vosa1702@gmail.com ${ }^{1 *}$, irdasari13@gmail.com ${ }^{2}$
}

Received: 01-08-2021

Revised : 18-10-2021

Accepted: 20-10-2021

\begin{abstract}
Abstrak
Latar Belakang: Kesadaran masyarakat tentang mutu pelayanan kesehatan tentunya juga dipengaruhi oleh tingkat pengetahuan masyarakat itu sendiri, hal ini terbukti bahwa sejak BPJS kesehatan menjangkau untuk semua kalangan masyarakat, banyak berbagai masukan perbaikan, kritik, dan saran ditujukan kepada pelayanan kesehatan di Indonesia yang bertujuan agar mutu pelayanan kesehatan di Indonesia semakin meningkat.
\end{abstract}

Tujuan: Penelitian ini bertujuan untuk mengetahui tingkat kepuasan pasien peserta BPJS Kesehatan terhadap mutu pelayanan kesehatan di UPTD Puskesmas Rawat Inap Ciranjang.

Metode: Jenis penelitian ini menggunakan metode penelitian deskriptif kuantitatif. Penelitian ini dilakukan pada bulan April s/d Juni 2021 di UPTD Puskesmas Rawat Inap Ciranjang. Sampel dalam penelitian ini sebanyak 64 orang. Teknik sampling yang diambil adalah accidental sampling. Metode pengumpulan data penelitian dengan menggunakan kuesioner dan diukur dengan skala likert.

Hasil: Hasil penelitian yang dilakukan oleh peneliti dapat disimpulkan bahwa tingkat kepuasan pasien peserta BPJS Kesehatan terhadap pelayanan Kesehatan di UPTD Puskesmas Rawat inap Ciranjang sudah puas dengan nilai persentase kepuasan sebesar $80 \%$.

Kesimpulan: Kesimpulan penelitian ini adalah Tingkat Kepuasan Pasien Peserta BPJS Kesehatan Terhadap Mutu pelayanan kesehatan di UPTD Puskesmas Rawat Inap Ciranjang sudah tergolong Puas dengan persentase sebesar $80 \%$. Berdasarkan hasil masing-masing dimensi yaitu dimensi Responsiveness 75\%, Assurance 85\%, Empathy 80\%, Tangible 85\%, dan Reliability 70\%.

Kata kunci: pelayanan kesehatan; peserta BPJS; tingkat kepuasan.

\footnotetext{
Abstract

Background: Public awareness about the quality of health services is of course also influenced by the level of knowledge of the community itself, it is evident that since BPJS Kesehatan reaches out to all circles of society, many
} 


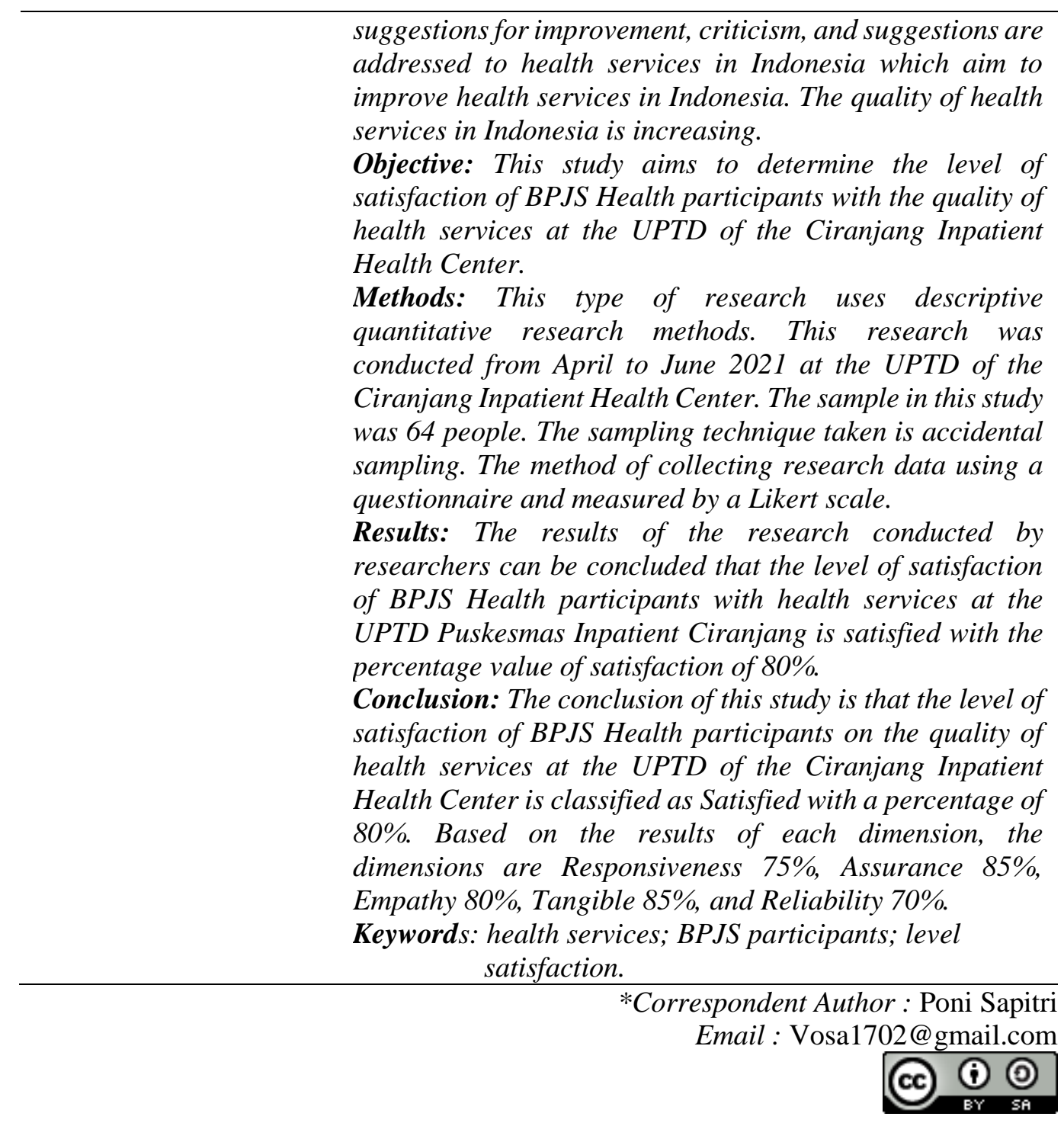

\section{PENDAHULUAN}

Kesehatan adalah sebuah sumber daya yang dimiliki semua manusia dan bukan merupakan suatu tujuan hidup yang perlu dicapai. Kesehatan tidak terfokus kepada fisik yang bugar tetapi meliputi jiwa yang sehat di mana individu dapat bersikap toleran dan dapat menerima perbedaan (Budhiarjo et al., 2021).

Puskesmas adalah fasilitas pelayanan kesehatan yang menyelenggarakan upaya kesehatan masyarakat dan upaya kesehatan perseorangan tingkat pertama, dengan lebih mengutamakan upaya promotif dan preventif, untuk mencapai derajat kesehatan masyarakat yang setinggi-tingginya di wilayah kerjanya (Permenkes, 2014).

Puskesmas sebagai fasilitas kesehatan tingkat pertama diharapkan dapat memperbaiki dan meningkatkan kesehatan masyarakat (Nazir \& Darmawati, 2018). Dimana para petugas atau tenaga kesehatan mempunyai peran dan tanggung jawab yang besar mengenai masalah kesehatan masyarakat. Terutama dalam hal pemberian pelayanan kesehatan yang bermutu kepada masyarakat (Fitri Andriana, 2021). Pemberian pelayanan kesehatan yang bermutu akan memberikan kepuasan bagi diri pasien yang berefek pada keinginan pasien untuk kembali ke institusi yang memberikan pelayanan kesehatan yang efektif (iyadi, 2015). 
Badan Penyelenggara Jaminan Sosial (BPJS) adalah badan hukum yang dibentuk untuk menyelenggarakan program jaminan kesehatan melalui Undang-Undang No.24 Tahun 2011. Semua penduduk Indonesia wajib menjadi peserta jaminan kesehatan yang dikelola oleh BPJS termasuk orang asing yang telah bekerja paling singkat enam bulan di Indonesia dan telah membayar iuran (KemenKes, 2013). Program Jaminan Kesehatan Nasional yang diselenggarakan oleh BPJS Kesehatan ini tentunya akan semakin berjalan maksimal jika diiringi dengan mutu pelayanan kesehatan yang baik oleh penyedia jasa kesehatan (Yunizar \& Nasution, 2020).

Kesadaran masyarakat tentang mutu pelayanan kesehatan tentunya juga dipengaruhi oleh tingkat pengetahuan masyarakat itu sendiri, hal ini terbukti bahwa sejak BPJS Kesehatan menjangkau untuk semua kalangan masyarakat, banyak berbagai masukan perbaikan, kritik, dan saran ditujukan kepada pelayanan kesehatan di Indonesia yang bertujuan agar mutu pelayanan kesehatan di Indonesia semakin meningkat (Sandra \& Witcahyo, n.d.).

Setelah ada program badan penyelenggara jaminan sosial (BPJS) dari pemerintah masyarakat dapat lebih mudah menggunakan pelayanan kesehatan, mulai dari masyarakat dengan status ekonomi rendah hingga dengan status ekonomi tinggi. Pelayanan kesehatan yang bermutu masih jauh dari harapan masyarakat. Penerima jasa pelayanan kesehatan di puskesmas menuntut pelayanan yang berkualitas tidak hanya menyangkut kesembuhan dari penyakit secara fisik akan tetapi juga menyangkut kepuasan terhadap sikap, pengetahuan dan keterampilan petugas dalam memberikan pelayanan serta tersedianya sarana dan prasarana yang memadai dan dapat memberikan kenyamanan (Widiastuti, 2017).

Tidak jarang ditemukan pasien yang mengeluh merasa tidak puas baik itu dari pelayanan yang diberikan maupun dari petugas yang melayaninya, karena dianggap kurang baik atau sopan saat berbicara dengan pasien serta para petugas yang sering datang terlambat (Asdiwinata \& Wulandari, 2021). Maka bukan hal yang tidak mungkin minat pasien untuk menggunakan jasa pelayanan di Puskesmas tersebut berkurang dan lebih memilih pelayanan kesehatan lain yang bisa memberikan jaminan kepuasan dengan pelayanan yang lebih baik (Simanjuntak \& Siallagan, 2017).

Penelitian yang dilakukan oleh Retno Eka Pratiwi pada tahun 2013 mengenai Kualitas Pelayanan Peserta Jaminan Kesehatan Masyarakat bagian Rawat Jalan di Puskesmas Sumbersari Kabupaten Jember membuktikan bahwa mutu atau kualitas pelayanan yang diberikan oleh Puskesmas Sumbersari belum memberikan kepuasan dalam diri pasien. Sebab harapan pasien lebih tinggi dari persepsi tentang mutu pelayanan kesehatan yang dirasakan oleh pasien peserta Jamkesmas (Eka \& Anwar, 2013).

Hasil penelitian lain Riezky Riyadi tahun 2015 mengenai Mutu Pelayanan Kesehatan Peserta Jaminan Kesehatan Nasional di Puskesmas Kecamatan Kembangan Jakarta Barat mengatakan bahwa mutu pelayanan kesehatan peserta Jaminan Kesehatan Nasional di Puskesmas Kecamatan Kembangan sudah tergolong baik, dengan hasil persentase kepuasan pasien sebesar 83,25\% (Riyadi, 2015).

Mengukur kualitas jasa pelayanan (service quality) dapat digunakan dimensi kualitas jasa yang dikemukakan oleh (Parasuraman et al., 1985). Kelima karakteristik tersebut adalah : Pertama, Tangibles (bukti langsung) meliputi fasilitas fisik, perlengkapan, pegawai dan sarana komunikasi. Kedua, Reliability (kehandalan) yaitu kemampuan memberikan pelayanan yang dijanjikan dengan segera, akurat dan memuaskan. Ketiga, Responsiveness (daya tanggap) yaitu keinginan para staff untuk membentuk para pelanggan dan memberikan pelayanan dengan tanggap. Keempat, Assurance (jaminan yang mencakup pengetahuan, kemampuan, kesopanan dan sifat dapat dipercaya yang dimiliki para staff bebas dari bahaya, resiko atau keragu-raguan). Penelitian ini bertujuan untuk mengetahui tingkat kepuasan pasien peserta BPJS Kesehatan terhadap mutu pelayanan kesehatan di UPTD Puskesmas Rawat Inap Ciranjang. 
Berdasarkan uraian-uraian diatas maka peneliti tertarik untuk melakukan penelitian dengan judul "Tingkat kepuasan pasien peserta BPJS Kesehatan terhadap mutu pelayanan kesehatan di UPTD Puskesmas Rawat Inap Ciranjang".

\section{METODE PENELITIAN}

Penelitian ini menggunakan pendekatan kuantitatif, karena pendekatan kuantitatif dapat menghasilkan data yang lebih akurat. Pendekatan kuantitatif ini merupakan salah satu pendekatan dalam penelitian yang lebih ditekankan pada data yang dapat dihitung untuk menghasilkan penafsiran kuantitatif yang kokoh. Adapun desain yang digunakan dalam penelitian ini adalah penelitian deskriptif. Penelitian deskriptif merupakan penelitian untuk memberi uraian mengenai fenomena atau gejala sosial yang diteliti dengan mendeskripsikan tentang nilai variabel mandiri baik satu variabel atau lebih (independent).

Penelitian ini dilakukan pada bulan April s/d Juni 2021. Penelitian dilakukan di UPTD Puskesmas Rawat Inap Ciranjang. Teknik sampling yang diambil adalah nonprobability sampling. nonprobability sampling adalah teknik pengambilan sampel yang tidak memberikan peluang atau kesempatan yang sama bagi setiap unsur atau anggota populasi untuk dipilih menjadi sampel (Sugiyono, 2017). Teknik sampel yang digunakan yakni accidental sampling yakni teknik penentuan sampel berdasarkan kebetulan, yaitu siapa yang secara kebetulan bertemu dengan peneliti dapat digunakan sebagai sampel.

Serta penelitian ini menggunakan teknik kuesioner ini sebanyak 64 kuesioner disebar kepada pasien peserta BPJS yang menggunakan fasilitas pelayanan kesehatan di UPTD Puskesmas Rawat Inap Ciranjang. Instrument dalam penelitian ini berbentuk kuesioner dengan variabel tunggal yaitu mutu pelayanan. Kuesioner, yaitu teknik pengumpulan data yang dilakukan dengan cara memberi seperangkat pertanyaan atau pernyataan tertulis mengenai variabel yang diteliti kepada responden untuk dijawab.

\section{HASIL DAN PEMBAHASAN}

\section{A. Hasil Penelitian}

Setelah melakukan penelitian tentang Tingkat kepuasan pasien peserta BPJS Kesehatan terhadap mutu pelayanan kesehatan di UPTD Puskesmas Rawat Inap Ciranjang berdasarkan dimensi Responsiveness (Daya Tanggap), Reliability (Kehandalan), Assurance (Jaminan), Empathy (Empati), Tangible (Bukti Fisik) dengan jumlah responden sebanyak 64 orang maka diperoleh hasil sebagai berikut:

\section{Karakteristik Responden}

Adapun penelitian yang dilakukan tentang Tingkat kepuasan pasien peserta BPJS Kesehatan terhadap mutu pelayanan kesehatan di UPTD Puskesmas Rawat Inap Ciranjang peneliti menemukan data-data yang relevan. Masing-masing responden memiliki penilaian yang berbeda-beda terhadap pelayanan tersebut.

Adapun distribusi frekuensi jumlah responden berdasarkan jenis kelamin dapat dilihat dalam tabel dibawah ini:

Tabel 1. Distribusi Frekuensi Karakteristik Responden Tingkat Kepuasan Pasien Peserta BPJS Kesehatan Terhadap Mutu Pelayanan Kesehatan di UPTD Puskesmas Rawat Inap Ciranjang Berdasarkan Jenis Kelamin Tahun 2021.

\begin{tabular}{cccc}
\hline No & Jenis Kelamin & Frekuensi & Persentase (\%) \\
\hline 1 & Laki-laki & 42 & $66 \%$ \\
\hline
\end{tabular}




\begin{tabular}{cccc}
\hline 2 & Perempuan & 22 & $34 \%$ \\
\hline Total & & 64 & $100 \%$ \\
\hline
\end{tabular}

Berdasarkan tabel 1 di atas dapat diketahui bahwa jumlah pasien yang menggunakan fasilitas pelayanan kesehatan dengan kartu BPJS Kesehatan di Puskesmas Ciranjang lebih banyak laki-laki dibandingkan perempuan. Laki-laki berjumlah 42 responden atau sebesar $66 \%$ sedangkan perempuan berjumlah 22 responden atau sebesar $34 \%$.

Tabel 2. Distribusi Frekuensi Karakteristik Tingkat Kepuasan Pasien Peserta BPJS Kesehatan Terhadap Mutu Pelayanan Kesehatan di UPTD Puskesmas Rawat Inap Ciranjang Berdasarkan usia Tahun 2021.

\begin{tabular}{cccc}
\hline No & Usia & Frekuensi & Persentase (\%) \\
\hline 1 & $18-28$ tahun & 23 & $36 \%$ \\
\hline 2 & $29-39$ tahun & 20 & $31 \%$ \\
\hline 3 & $40-50$ tahun & 15 & $24 \%$ \\
\hline 4 & $>50$ tahun & 6 & $9 \%$ \\
\hline Total & & 64 & $100 \%$ \\
\hline
\end{tabular}

Berdasarkan tabel 2 diketahui bahwa jumlah pasien yang menggunakan fasilitas pelayanan kesehatan di Puskesmas Ciranjang dengan kartu BPJS Kesehatan lebih banyak yang berusia 18-28 tahun sebanyak 23 responden atau sebesar $36 \%$. Selanjutnya yang berusia 29-39 tahun berjumlah 20 responden atau sebesar 31\%, pasien yang berusia 40-50 tahun sebanyak 15 responden atau sebesar $24 \%$, sedangkan yang berusia $>50$ tahun sebanyak 6 responden atau sebesar $9 \%$.

Tabel 3. Distribusi Frekuensi Karakteristik Responden Tingkat kepuasan pasien peserta BPJS Kesehatan terhadap mutu pelayanan kesehatan di UPTD Puskesmas Rawat Inap Ciranjang berdasarkan Pendidikan Tahun 2021.

\begin{tabular}{cccc}
\hline No & Pendidikan & Frekuensi & Persentase \\
\hline 1 & SD & 10 & $16 \%$ \\
\hline 2 & SMP & 23 & $36 \%$ \\
\hline 3 & SMA & 25 & $39 \%$ \\
\hline 4 & Perguruan Tinggi & 6 & $9 \%$ \\
\hline Total & & 64 & $100 \%$ \\
\hline
\end{tabular}

Berdasarkan table 3 di atas dapat diketahui bahwa jumlah pasien yang menggunakan fasilitas pelayanan kesehatan di Puskesmas Ciranjang dengan kartu BPJS Kesehatan lebih banyak yang berpendidikan terakhir SMA sebanyak 25 responden atau sebesar 39\%, selanjutnya yang berpendidikan terakhir SMP sebanyak 23 responden atau sebesar $36 \%$, dan yang berpendidikan terakhir SD sebanyak 10 responden atau sebesar $16 \%$ sedangkan pasien yang berpendidikan terakhir perguruan tinggi hanya sebanyak 6 orang atau sebesar $9 \%$.

Tabel 4. Tingkat Kepuasan Pasien Peserta BPJS Kesehatan Terhadap Mutu Pelayanan Kesehatan di UPTD Puskesmas Rawat Inap Ciranjang Berdasarkan Dimensi Responsiveness (Daya Tanggap) Tahun 2021.

\begin{tabular}{clcccccc}
\hline No & \multicolumn{1}{c}{ Pernyataan } & SP & P & CP & TP & STP & Skor \\
\hline 1 & $\begin{array}{l}\text { Dokter memberikan } \\
\text { kesempatan bertanya kepada } \\
\text { pasien }\end{array}$ & 18 & 29 & 17 & 0 & 0 & 257 \\
& & & & & & \\
\hline
\end{tabular}




\begin{tabular}{clllllll}
\hline 2 & $\begin{array}{l}\text { Dokter dan Petugas Puskesmas } \\
\text { bersikap ramah dan sopan }\end{array}$ & 15 & 28 & 15 & 6 & 0 & 244 \\
\hline 3 & $\begin{array}{l}\text { Waktu tunggu di pendaftaran } \\
\text { sebentar }\end{array}$ & 0 & 15 & 28 & 21 & 0 & 186 \\
\hline 4 & $\begin{array}{c}\text { Kecepatan dan ketepatan } \\
\text { penyerahan obat }\end{array}$ & 18 & 35 & 11 & 0 & 0 & 263 \\
\hline $\mathbf{X = 2 3 7 , 5}$ & & & & & & $\mathbf{9 5 0}$
\end{tabular}

Berdasarkan tabel 4 pengumpulan data yang peneliti lakukan terhadap 64 orang mengenai Tingkat kepuasan pasien peserta BPJS Kesehatan terhadap mutu pelayanan kesehatan di UPTD Puskesmas Rawat Inap Ciranjang. Pendapatan responden terhadap pernyataan pertama yang menyatakan bahwa dokter memberikan kesempatan bertanya kepada pasien sebanyak 18 orang menyatakan sangat puas, 29 menyatakan puas, 17 orang menyatakan cukup puas.

Pernyataan kedua, pendapat responden yang menyatakan dokter dan petugas Puskesmas bersikap ramah dan sopan, sebanyak 15 orang menyatakan sangat puas, 28 orang menyatakan puas dan 15 orang menyatakan cukup puas sedangkan 6 orang menyatakan tidak puas. Kemudian pernyataan ketiga pendapat responden mengenai waktu tunggu di pendaftaran sebentar, yang menyatakan puas sebanyak 15 orang, yang menyatakan cukup sebanyak 28 orang, dan 21 orang menyatakan tidak puas.

Selanjut nya pernyataan ke empat, pendapat responden mengenai kecepatan dan ketepatan penyerahan obat, 18 orang menyatakan sangat puas, yang menyatakan puas sebanyak 35 orang dan 11 orang menyatakan tidak puas. Berdasarkan data di atas menunjukan bahwa banyak pasien yang menyatakan puas terhadap pelayanan yang diberikan pihak Puskesmas Ciranjang dalam hal Responsiveness (daya tanggap).

Tabel 5. Tingkat Kepuasan Pasien Peserta BPJS Kesehatan Terhadap Mutu Pelayanan Kesehatan di UPTD Puskesmas Rawat Inap Ciranjang Berdasarkan Dimensi Assurance (Jaminan) Tahun 2021

\begin{tabular}{|c|c|c|c|c|c|c|c|}
\hline No & Pernyataan & SP & $\mathbf{P}$ & CP & TP & STP & Skor \\
\hline 1 & $\begin{array}{l}\text { Petugas Puskesmas terdidik dan mampu } \\
\text { melayani pasien dengan baik }\end{array}$ & 18 & 30 & 16 & 0 & 0 & 258 \\
\hline 2 & $\begin{array}{l}\text { Biaya pengobatan di Puskesmas sepenuh } \\
\text { nya gratis. }\end{array}$ & 23 & 35 & 6 & 0 & 0 & 273 \\
\hline 3 & $\begin{array}{l}\text { Dokter dan petugas Puskesmas menjaga } \\
\text { kerahasiaan pasien }\end{array}$ & 44 & 20 & 0 & 0 & 0 & 300 \\
\hline 4 & $\begin{array}{l}\text { Perilaku Dokter dan Petugas Puskesmas } \\
\text { menimbulkan rasa aman }\end{array}$ & 20 & 33 & 11 & 0 & 0 & 265 \\
\hline$X=$ & 274 & & & & & & 1096 \\
\hline
\end{tabular}

Berdasarkan tabel 5 pendapat responden mengenai pernyataan pertama yang menyatakan petugas Puskesmas terdidik dan mampu melayani pasien dengan baik, sebanyak 18 orang menyatakan sangat puas, yang menyatakan puas sebanyak 30 orang dan 16 orang menyatakan cukup puas. Tidak ada pasien yang menyatakan tidak puas atau bahkan sangat tidak puas. Selanjutnya pendapat responden mengenai pernyataan kedua yang menyatakan biaya pengobatan di Puskesmas sepenuh nya gratis, yang menyatakan sangat puas 23 orang, yang menyatakan puas 35 orang dan yang menyatakan cukup puas sebanyak 6 orang. Tidak ada responden yang menyatakan tidak puas atau sangat tidak puas.

Kemudian pendapat responden mengenai pernyataan ketiga yang menyatakan Dokter dan Petugas Puskesmas menjaga kerahasiaan pasien, 44 orang menyatakan sangat puas, dan 20 orang menyatakan puas. Tidak ada responden yang menyatakan tidak puas atau bahkan sangat tidak puas. Dan pendapat responden mengenai pernyataan ke empat 
yang menyatakan perilaku dokter dan petugas puskesmas menimbulkan rasa aman, 20 orang menyatakan sangat puas, 33 orang menyatakan puas dan 11 orang menyatakan cukup puas, tidak ada pasien yang memberikan jawaban tidak puas atau bahkan sangat tidak puas.

Dari data diatas menunjukan bahwa banyak pasien yang menyatakan puas terhadap pelayanan yang diberikan pihak Puskesmas Ciranjang dalam hal Assurance (Jaminan).

Tabel 6. Tingkat Kepuasan Pasien Peserta BPJS Kesehatan Terhadap Mutu Pelayanan Kesehatan di UPTD Puskesmas Rawat Inap Ciranjang Berdasarkan Dimensi Empathy (empati) Tahun 2021.

\begin{tabular}{|c|c|c|c|c|c|c|c|}
\hline No & Pernyataan & SP & $\mathbf{P}$ & $\mathbf{C P}$ & $\mathbf{T P}$ & STP & Skor \\
\hline & $\begin{array}{l}\text { Dokter selalu menanyakan kabar dan } \\
\text { keadaan pasien }\end{array}$ & 10 & 33 & 21 & 0 & 0 & 245 \\
\hline & $\begin{array}{l}\text { Petugas Puskesmas selalu } \\
\text { mengingatkan keamanan akan } \\
\text { menyimpan barang berharga pasien }\end{array}$ & 24 & 40 & 0 & 0 & 0 & 280 \\
\hline & $\begin{array}{l}\text { Dokter dan Petugas Puskesmas selalu } \\
\text { tersenyum pada pasien }\end{array}$ & 6 & 44 & 14 & 0 & 0 & 248 \\
\hline & $\begin{array}{l}\text { Kesediaan petugas untuk minta maaf } \\
\text { bila terjadi kesalahan }\end{array}$ & 15 & 43 & 6 & 0 & 0 & 265 \\
\hline
\end{tabular}

Berdasarkan tabel 6, pendapat responden mengenai pernyataan pertama yang menyatakan Dokter selalu menanyakan kabar dan keadaan pasien, 10 orang menyatakan sangat puas, 33 orang menyatakan puas dan 21 orang menyatakan cukup puas. Tidak ada yang menyatakan tidak puas atau bahkan sangat tidak puas.

Pendapat responden mengenai pernyataan kedua yang menyatakan Petugas Puskesmas selalu mengingatkan keamanan akan menyimpan barang berharga pasien, 24 orang menyatakan sangat puas, sedangkan 40 orang menyatakan puas dan tidak ada pasien yang menyatakan tidak puas. Kemudian Pendapat responden mengenai pernyataan ketiga yang menyatakan Dokter dan Petugas Puskesmas selalu tersenyum pada pasien, 6 orang menyatakan sangat puas, 44 orang menyatakan puas dan 14 orang menyatakan cukup puas, tidak ada pasien yang menyatakan tidak puas.

Selanjutnya Pendapat responden mengenai pernyataan ke 4 yang menyatakan Kesediaan petugas untuk minta maaf bila terjadi kesalahan, 15 orang menyatakan sangat puas, 43 orang menyatakan puas dan 6 orang lagi menyatakan cukup puas. Tidak ada pasien yang menyatakan tidak puas atau bahkan sangat tidak puas. Berdasarkan data di atas menunjukan bahwa banyak pasien yang menyatakan puas terhadap pelayanan yang diberikan pihak Puskesmas Ciranjang dalam hal Empathy (empati).

Tabel 7. Tingkat Kepuasan Pasien Peserta Bpjs Kesehatan Terhadap Mutu Pelayanan Kesehatan di UPTD Puskesmas Rawat Inap Ciranjang Berdasarkan Dimensi Tangible (bukti fisik) Tahun 2021.

\begin{tabular}{clcccccc}
\hline No & \multicolumn{1}{c}{ Pernyataan } & SP & P & CP & TP & STP & Skor \\
\hline 1 & $\begin{array}{l}\text { Tersedia papan petunjuk arah lokasi } \\
\text { keberadaan ruangan }\end{array}$ & 28 & 30 & 6 & 0 & 0 & 278 \\
\hline 2 & $\begin{array}{l}\text { Lingkungan Puskesmas bersih dari } \\
\text { sampah }\end{array}$ & 25 & 29 & 10 & 0 & 0 & 271 \\
\hline 3 & $\begin{array}{l}\text { Ruang pemeriksaan tertata rapi, } \\
\text { bersih dan nyaman }\end{array}$ & 28 & 35 & 1 & 0 & 0 & 283 \\
\hline 4 & $\begin{array}{l}\text { Penampilan Dokter dan Petugas } \\
\text { Puskesmas lainnya rapi dan bersih }\end{array}$ & 29 & 35 & 0 & 0 & 0 & 285 \\
\hline $\mathbf{X = 2 7 9 , 2}$ & & & & & & 1117 \\
\hline
\end{tabular}


Berdasarkan tabel 7 , pendapat responden mengenai pernyataan pertama yang menyatakan Tersedia papan petunjuk arah lokasi keberadaan ruangan, 28 orang menyatakan sangat puas, 30 orang menyatakan puas dan 6 orang menyatakan cukup puas. Tidak ada responden yang menyatakan tidak puas atau bahkan sangat tidak puas.

Pendapat responden mengenai pernyataan kedua yang menyatakan Lingkungan Puskesmas bersih dari sampah, 25 orang menyatakan sangat puas, yang menyatakan puas 29 orang dan 10 orang menyatakan cukup puas. Tidak ada responden yang menyatakan tidak puas atau bahkan sangat tidak puas.

Kemudian pendapat responden mengenai pernyataan ketiga yang menyatakan Ruang pemeriksaan tertata rapi, bersih dan nyaman, 25 orang menyatakan sangat puas, 29 orang menyatakan puas dan tidak ada responden yang menyatakan tidak puas atau bahkan sangat tidak puas. Selanjutnya pendapat responden mengenai pernyataan ke empat yang menyatakan Penampilan Dokter dan Petugas Puskesmas lainnya rapi dan bersih, 29 orang menyatakan sangat puas, 35 orang menyatakan puas. Tidak ada responden yang menyatakan tidak puas atau bahkan sangat tidak puas.

Dari data diatas menunjukan bahwa banyak pasien yang menyatakan puas terhadap pelayanan yang diberikan pihak Puskesmas Ciranjang dalam hal Tangible (bukti fisik).

Tabel 8. Tingkat Kepuasan Pasien Peserta BPJS Kesehatan Terhadap Mutu Pelayanan Kesehatan di Uptd Puskesmas Rawat Inap Ciranjang Berdasarkan Dimensi Reliability (kehandalan) TAHUN 2021.

\begin{tabular}{llllllll}
\hline No & Pernyataan & SP & P & CP & TP & STP & Skor \\
\hline 1 & $\begin{array}{l}\text { Pendaftaran pasien dilayani dengan } \\
\text { cepat dan tidak berbelit-belit }\end{array}$ & 16 & 20 & 20 & 8 & 0 & 236 \\
\hline 2 & Dokter datang tepat waktu & 3 & 15 & 20 & 26 & 0 & 187 \\
\hline 3 & $\begin{array}{l}\text { Dokter dan Petugas lainnya bersikap } \\
\text { ramah saat menangani pasien }\end{array}$ & 13 & 30 & 15 & 6 & 0 & 242 \\
\hline 4 & $\begin{array}{l}\text { Petugas apotek memberikan penjelasan } \\
\text { tentang pemakaian obat }\end{array}$ & 18 & 40 & 6 & 0 & 0 & 268 \\
\hline $\mathrm{X}=233,2$ & & & & & & 933 \\
\hline
\end{tabular}

Berdasarkan tabel 8 , pendapat responden mengenai pernyataan pertama yang menyatakan Pendaftaran pasien dilayani dengan cepat dan tidak berbelit-belit, 16 orang menyatakan sangat puas, 20 orang menyatakan puas dan yang menyatakan cukup puas sebanyak 20 orang sedangkan 8 orang menyatakan tidak puas.

Pendapat responden mengenai pernyataan kedua yang menyatakan Dokter datang tepat waktu, hanya 3 orang yang menyatakan sangat puas, 15 orang menyatakan puas, 20 orang menyatakan cukup puas dan sebanyak 26 orang menyatakan tidak puas. Kemudian pendapat responden mengenai pernyataan ketiga yang menyatakan Dokter dan Petugas lainnya bersikap ramah saat menangani pasien, sebanyak 13 orang menyatakan sangat puas, 30 orang menyatakan puas dan 15 orang menyatakan cukup puas sementara 6 orang lagi menyatakan tidak puas.

Selanjutnya pendapat responden mengenai pernyataan ke empat yang menyatakan Petugas apotek memberikan penjelasan tentang pemakaian obat, sebanyak 18 orang menyatakan sangat puas, 40 orang menyatakan puas dan 6 orang menyatakan cukup puas. Tidak ada responden yang menyatakan tidak puas atau bahkan sangat tidak puas.

Dari data diatas menunjukan bahwa banyak pasien yang menyatakan puas terhadap pelayanan yang diberikan pihak Puskesmas Ciranjang dalam hal Reliability (kehandalan).

\section{Interpretasi data}


Tabel 9. Kategori Jawaban Responden

\begin{tabular}{llccccc}
\hline No & Dimensi & Skor & $\begin{array}{c}\text { Nilai } \\
\text { Harapan } \\
\text { (NH) }\end{array}$ & $\begin{array}{c}\text { Nilai Skor } \\
\text { (NS) }\end{array}$ & $\begin{array}{c}\text { P=NS/NH X } \\
\mathbf{1 0 0 \%}\end{array}$ & $\begin{array}{c}\text { Kategori } \\
\text { nilai }\end{array}$ \\
\hline 1 & $\begin{array}{l}\text { Responsiveness } \\
\text { (Daya Tanggap) }\end{array}$ & 950 & $4 \times 5=20$ & $950 / 64=15$ & $15 / 20 \times 100 \%=75 \%$ & Puas \\
\hline 2 & $\begin{array}{l}\text { Assurance } \\
\text { (Jaminan) }\end{array}$ & 1096 & $4 \times 5=20$ & $1096 / 64=17$ & $17 / 20 \times 100 \%=85 \%$ & Puas \\
\hline 3 & $\begin{array}{l}\text { Empathy } \\
\text { (empati) }\end{array}$ & 1038 & $4 \times 5=20$ & $1038 / 64=16$ & $16 / 20 \times 100 \%=80 \%$ & Puas \\
\hline 4 & $\begin{array}{l}\text { Tangible } \\
\text { (bukti fisik) }\end{array}$ & 1117 & $4 \times 5=20$ & $1117 / 64=17$ & $17 / 20 \times 100 \%=85 \%$ & Puas \\
\hline 5 & $\begin{array}{l}\text { Reliability } \\
\text { (kehandalan) }\end{array}$ & 933 & $4 \times 5=20$ & $933 / 64=14$ & $14 / 20 \times 100 \%=70 \%$ & $\begin{array}{c}\text { Cukup } \\
\text { Puas }\end{array}$ \\
\hline Rata-rata & 5134 & $20 \times 5=100$ & $5134 / 64=80$ & $80 / 100 \times 100 \%=80 \%$ & Puas \\
\hline
\end{tabular}

Berdasarkan tabel 9 data dari hasil penyebaran kuesioner terhadap 64 responden yang terdiri dari 5 dimensi. Data yang diperoleh kemudian diinterpretasikan. Interpretasi hasil penelitian dimaksudkan untuk memperoleh nilai rata- rata setiap dimensi variabel penelitian.

\section{B. Pembahasan}

\section{Dimensi Responsiveness (Daya Tanggap)}

Hasil dari pendapat responden mengenai tingkat kepuasan pasien peserta BPJS Kesehatan terhadap kualitas pelayanan dari segi dimensi responsiveness (daya tanggap) adalah sebesar $75 \%$ yang artinya pasien sudah merasa puas terhadap kualitas pelayanan Puskesmas Ciranjang. Hal ini sejalan dengan penelitian yang dilakukan oleh (Almardiah \& Habibi, 2018), Petugas kesehatan dinilai mampu menolong pelanggan dan melayani sesuai prosedur dan bisa memenuhi harapan pelanggan.

\section{Dimensi Assurance (Jaminan)}

Dimensi assurance berkaitan dengan pengetahuan, kesopansantunan dan kemampuan para pegawai Puskesmas menumbuhkan rasa percaya pada pasien. Tingkat kepuasan pasien peserta BPJS kesehatan dalam segi assurance ini sebesar $85 \%$ yang artinya pasien sudah merasa puas terhadap kualitas pelayanan Puskesmas Ciranjang. Hal ini sejalan dengan penelitian yang dilakukan oleh (Parasuraman et al., 1985), Pemenuhan terhadap kriteria pelayanan ini akan mengakibatkan pengguna jasa merasa terbebas dari resiko.

\section{Dimensi Empathy (empati)}

Hasil dari pendapat responden mengenai tingkat kepuasan pasien peserta BPJS Kesehatan terhadap kualitas pelayanan yang diwakili oleh dimensi empathy adalah sebesar $80 \%$ artinya pasien sudah merasa puas terhadap kualitas pelayanan Puskesmas Ciranjang hal ini sejalan dengan penelitian yang dilakukan oleh (Almardiah \& Habibi, 2018), Kriteria ini terkait dengan rasa kepedulian dan perhatian khusus staf kepada setiap pengguna jasa pelayanan kesehatan dan memahami kebutuhan mereka.

\section{Dimensi Tangible (bukti fisik)}

Hasil dari pendapat responden mengenai tingkat kepuasan pasien peserta BPJS Kesehatan terhadap kualitas pelayanan yang diwakili oleh dimensi tangible adalah sebesar 
$85 \%$ artinya pasien sudah merasa puas terhadap kualitas pelayanan Puskesmas Ciranjang. Hal ini sejalan dengan teori Parasuraman, (Riyadi, 2015), mutu jasa pelayanan kesehatan juga dapat dirasakan secara langsung oleh penggunanya dengan menyediakan fasilitas fisik dan perlengkapan yang memadai. Para penyedia layanan kesehatan akan mampu bekerja secara optimal sesuai keterampilannya masing- masing.

Berdasarkan hasil rata-rata yang diperoleh dari kelima dimensi Mutu Pelayanan Kesehatan, UPTD Puskesmas Rawat Inap Ciranjang tingkat kepuasan pasien peserta BPJS Kesehatan memiliki nilai yang cukup tinggi yaitu sebesar $80 \%$.

\section{KESIMPULAN}

Berdasarkan hasil penelitian dan pembahasan yang telah dikemukakan di bab sebelumnya maka dapat diperoleh kesimpulan bahwa Tingkat Kepuasan Pasien Peserta BPJS Kesehatan Terhadap Mutu pelayanan kesehatan di UPTD Puskesmas Rawat Inap Ciranjang sudah tergolong Puas dengan persentase sebesar $80 \%$. Dengan hasil masingmasing dimensi yaitu dimensi Responsiveness 75\%, Assurance 85\%, Empathy 80\%, Tangible 85\%, dan Reliability $70 \%$.

\section{BIBLIOGRAFI}

Almardiah, A., \& Habibi, M. (2018). Hubungan Mutu Pelayanan dengan Minat Kunjungan Ulang Pasien Rawat Jalan di Klinik Islamic Center Kota Samarinda.

Asdiwinata, I. N., \& Wulandari, I. G. A. P. D. (2021). Gambaran Kualitas Pelayanan Kesehatan di Poliklinik Jantung. Jurnal Keperawatan, 13(2), 123-136.

Budhiarjo, I. S., Arif, F., Susilawati, S., Akbar, A. R., \& Anggraeni, R. P. (2021). Penyuluhan Peran Organisasi Karang Taruna Dalam Pelatihan Peningkatan Kesehatan Dan Perencanaan Keuangan Di Masa Pandemi. Jurnal Abdimas Tri Dharma Manajemen, 2(3), 62-74.

Eka, P. R., \& Anwar, D. S. (2013). Kualitas Pelayanan Kesehatan Peserta Jamkesmas Bagian Rawat Jalan Di Kesehatan Sumbersari. Artikel Ilmiah Hasil Penelitian Ilmu Administrasi, Fakultas Ilmu Sosial Dan Ilmu Politik, Universitas Jember.

Fitri Andriana, F. A. (2021). Perlindungan hukum terhadap bidan dalam pemberian pelayanan kesehatan di poskesdes Kabupaten Majene. Universitas Hasanuddin.

KemenKes, R. I. (2013). Riset kesehatan dasar (Riskesdas) 2013. Jakarta: Badan Penelitian Dan Pengembangan Kesehatan Kementrian Kesehatan Republik Indonesia.

Nazir, N., \& Darmawati, G. (2018). Perancangan Pencatatan Dan Pelaporan Terpadu Puskesmas Berbasis E-Report Untuk Meningkatkan Kesehatan Masyarakat. Jurnal Sains Dan Teknologi: Jurnal Keilmuan Dan Aplikasi Teknologi Industri, 18(2), 7581. http://dx.doi.org/10.36275/stsp.v18i2.109.

Parasuraman, A., Zeithaml, V. A., \& Berry, L. L. (1985). A conceptual model of service quality and its implications for future research. Journal of Marketing, 49(4), 41-50. https://doi.org/10.1177/002224298504900403.

Permenkes, R. I. (2014). Peraturan Menteri Kesehatan Republik Indonesia Nomor 75 tahun 2014, tentang Pusat Kesehatan Masyarakat. Jakarta: Menteri Kesehatan Republik Indonesia, 3-23.

Riyadi, R. (2015). Mutu pelayanan kesehatan peserta jaminan kesehatan nasional di puskesmas Kecamatan Kembangan Jakarta Barat.

Sandra, M., \& Witcahyo, E. (n.d.). Perbedaan kepuasan antara pasien peserta jaminan kesehatan nasional dengan umum berdasarkan mutu pelayanan kesehatan di instalasi rawat inap rsd dr. Soebandi jember.

Tingkat Kepuasan Pasien Peserta BPJS Kesehatan Terhadap Mutu Pelayanan

Kesehatan di UPTD Puskesmas Rawat Inap Ciranjang 
Simanjuntak, M., \& Siallagan, H. (2017). Faktor-faktor yang Mempengaruhi Mutu Pelayanan Kesehatan Pasien Peserta Bpjs di Puskesmas Glugur Kota Medan. Jurnal Ilmiah Perekam Dan Informasi Kesehatan Imelda (JIPIKI), 2(2), 316-326.

Sugiyono. (2017). Metode Penelitian Kuantitatif, Kualitatif dan R\&D. Alfabeta.

Widiastuti, I. (2017). Pelayanan Badan Penyelenggara Jaminan Sosial (BPJS) Kesehatan di Jawa Barat. Public Inspiration: Jurnal Administrasi Publik, 2(2), 91-101. https://doi.org/10.22225/pi.2.2.2017.91-101

Yunizar, A., \& Nasution, N. H. (2020). Faktor-Faktor Yang Berhubungan Dengan Pemanfaatan Bpjs Di Desa Pargarutan Tonga Kecamatan Angkola Timur Tahun 2019. Jurnal Kesehatan Ilmiah Indonesia (Indonesian Health Scientific Journal), $5(1), 61-70$.

(C) 2021 by the authors. Submitted for possible open access publication under the (c) (D) (2) terms and conditions of the Creative Commons Attribution (CC BY SA) license (https://creativecommons.org/licenses/by-sa/4.0/). 